\title{
NOSARGĀT PARLAMENTĀRISMU: 5. SAEIMA UN SATVERSME
}

\section{TO PROTECT PARLIAMENTARY SYSTEM: THE $5^{\text {th }}$ SAEIMA AND THE CONSTITUTION}

\author{
Jānis Pleps, Dr. iur.
}

Latvijas Universitātes Juridiskās fakultātes

Tiesību teorijas un vēstures zinātṇu katedras docents

\section{Summary}

The Republic of Latvia Parliament, the $5^{\text {th }}$ Saeima on July 6, 1993 restored the Constitution of Latvia that was originally adopted on February 15, 1922. The restoration of the Constitution also meant a renewal of the parliamentary system as a form of governance in Latvia.

The $5^{\text {th }}$ Saeima during its term of office strengthened the parliamentary system and removed potential threats to changing the form of governance. The $5^{\text {th }}$ Saeima's position was determined by the conceptual decisions of the leading political force at that time political union "Latvijas Celšs".

The $5^{\text {th }}$ Saeima rejected the proposed amendments to the Constitution and laws that increased the powers of the state president. The majority of the $5^{\text {th }}$ Saeima also elected a state president who supported the parliamentary system established by the Constitution and did not become a political opponent of the Saeima.

Guntis Ulmanis, the first President of the State after restoration of the Constitution, re-established the presidential institution in accordance with the political principles of the parliamentary system.

Atslēgvārdi: Satversme, parlamentārisms, Valsts prezidents, Valsts prezidenta pilnvaras, Saeima

Keywords: Constitution, parliamentary system, state president, functions of state president, parliament

\section{Ievads}

Latvijas Republikas Satversmes ${ }^{1}$ (turpmāk - Satversme) darbības atjaunošana pilnā apjomā ${ }^{2}$ vienlaikus ar 5. Saeimas sanākšanu uz pirmo sēdi 1993. gada 6. jūlijā nozīmēja Satversmē noteiktās valsts iekārtas atjaunošanu. Šāds tiesībpolitisks lēmums bija pietiekami liels izaicinājums, jo tas nozīmēja parlamentārās

1 Latvijas Republikas Satversme: LV likums. [06.07.1993. red.].

2 Latvijas Republikas Saeimas paziņojums. Latvijas Republikas Saeimas un Ministru kabineta Ziṇotājs, 1993, Nr. 30. 
demokrātijas jeb parlamentārisma atjaunošanu. ${ }^{3}$ Parlamentārisms Latvijas valstiskuma vēsturē jau vienu reizi bija noraidìts 1934. gada 15. maija apvērsumā, ${ }^{4}$ un autoritārā režīma laiku raksturoja nesaudzīga parlamentārisma kritika. ${ }^{5}$ Lìdztekus vēsturiskajā atmiṇā saglabātajai skepsei pret parlamentārismu un romantizētajiem priekšstatiem par Kārḷa Ulmaņa autoritāro režìmu Latvijā ${ }^{6}$ pēc neatkarības atjaunošanas trūka praktisku zināšanu par parlamentārisma funkcionēšanu. Parlamentārisma pieredzi ierobežotā veidā bija iespējams apgūt Augstākās padomes darbības laikā, kad pārejas perioda valsts iekārta vairāk vai mazāk funkcionēja atbilstoši parlamentārisma principiem (lai gan būtiska ietekme bija arī padomju okupācijas perioda mantojumam). ${ }^{7}$

Konstitucionālo tiesību teorijā ir atzīta parlamentārisma transformēšanās iespēja - pārveidošanās sistēmā, kur prezidents faktiski kḷūst par dominējošo valsts varas orgānu, ja noteicošo pārsvaru pār parlamentu iegūst vienas personas autokrātiskā ietekme. ${ }^{8}$ Savukārt ilgtermiṇā vienas personas izšķiroša ietekme var nostiprināt nedemokrātisku režīmu un pakḷaut citus valsts varas orgānus, likvidējot valsts varas dalīšanu. ${ }^{9}$ Pēc sociālistiskās sistēmas sabrukuma potenciālos riskus apzinājās arī Centrāleiropas un Austrumeiropas valstis. ${ }^{10}$ Demokrātisko tradīciju trūkums un valsts varas dalīšanas sistēmas vājums daudzviet sekmēja nedemokrātisku režīmu izveidošanos, formāli saglabājot pusprezidentālas vai prezidentālas republikas konstitucionālo ietvaru. ${ }^{11}$ Latvijas gadijumā būtiski bija ne vien atjaunot Satversmes darbību pilnā apjomā, bet arī principiāli nostiprināt parlamentārismu praksē, novēršot iespējamos valsts iekārtas transformācijas riskus.

Šajā ziṇā nepelnīti aizmirsts un tiesību vēsturē maz pētīts ir 5. Saeimas paveiktais Latvijas valsts iekārtas konstitucionālajā atjaunošanā un nostiprināšanā. ${ }^{12}$ Šajā rakstā autors turpinās iepriekš aizsākto pētỉjumu par Satversmes piemērošanu

${ }^{3}$ Levits E. Latvijas tiesību sistēmas attīstības iezīmes uz XXI gadsimta sliekšṇa. Grām.: Latvijas tiesību vēsture (1914 - 2000). Prof. D. A. Lēbera redakcijā. Rīga: LU žurnāla "Latvijas Vēsture" fonds, 2000, 493. lpp. Plašāk sk.: Levits E. Demokrātiskā valsts iekārta, brīvas vēlešanas un parlamentārā demokrātija. Grām.: Parlamentārā izmeklēšana Latvijā. 1. parlaments. Parlamentārā kontrole. Prof. R. Baloža redakcijā. Rīga: Latvijas Vēstnesis, 2016, 39.-49. lpp.

${ }^{4}$ Plašāk sk.: Ščerbinskis V. 1934. gada 15. maija apvērsums: cēloņi, norise un sekas. Grām.: Apvērsums. 1934. gada 15. maija notikumi avotos un pētījumos. Sast. V. Ščerbinskis, Ē. Jēkabsons. Rīga: Latvijas Nacionālais arhīvs, 2012, 19.-24. lpp.

5 Piemēram: Virza E. Kārlis Ulmanis. Rīga: Zemnieku Domas, 1935; Dišlers K. Autoritāras valsts pamatprincipi. Rìga: Valters un Rapa, 1937.

6 Plašāk sk.: Naglinska E. Mīts par Kārli Ulmani latviešu presē (1989-2004). Grām.: Reiz dzīvoja Kārlis Ulmanis... Zelče V. (zin. red.). Rīga: Zinātne, 2007, 30.-97. lpp.

7 Levits E. Jaunā pamatlikuma projektu analizējot (IV). Diena, 1991, Nr. 152, 2. lpp.; Kusiņš G. Latvijas parlamentārisma apskats. Rīga: Latvijas Republikas Saeima, 2016, 57. lpp. Plašāk sk.: Jundzis T. Latvijas valsts atjaunošanas parlamentārais ceḷš. 1989-1993. Rīga: LZA Baltijas stratēǵisko pētījumu centrs, 2010, 25.-30. lpp.

${ }^{8}$ Schmitt C. Constitutional Theory. Durham and London: Duke University Press, 2008, pp. 328-330; Kelsen H. General Theory of Law and State. New Brunswick and London: Transaction Publishers, 2006, p. 301

9 Fix-Fierro H., Salazar-Ugarte P. Presidentialism. In: The Oxford Handbook of Comparative Constitutional Law. Ed. by M. Rosenfeld and A. Sajó. Oxford: Oxford University Press, 2012, pp. 638-639.

10 Plašāk sk.: Lamentovičs V. Mūsdienu valsts. 2. izd. Rīga: Zvaigzne ABC, 2007, 129.-132. lpp.

11 Fix-Fierro H., Salazar-Ugarte P. 2012, p. 639. Sk. arī: Краснов М. А. Персоналистский режим в России: опыт институционального анализа. Москва: Фонд «Либеральная миссия», 2006. Pieejams: http://www.liberal.ru/upload/files/krasn.pdf [aplūkots 17.04.2019.].

12 Sal.: Levits E. Latvijas tiesību attīstība kopš 1990. gada - no padomju sistēmas uz modernu Eiropas Savienības dalībvalsts tiesību sistēmu. Augstākās tiesas biḷetens, 2018, Nr. 17, 56.-57. lpp. 
pēc tās darbības atjaunošanas pilnā apjomā. ${ }^{13}$ Raksta mērḳis ir analizēt konkrētus 5. Saeimas tiesībpolitiskos lēmumus, kas sekmēja Satversmē noteiktās valsts iekārtas sekmīgu atjaunošanu praksē. Pēc raksta autora ieskata, kā šādi būtiski 5. Saeimas lēmumi vērtējami Satversmes reformas noraidī̌̌ana, pirmā Valsts prezidenta izraudzišanās pēc Satversmes darbības atjaunošanas pilnā apjomā, kā arī atteikšanās likumdošanas ceḷā paredzēt papildu Valsts prezidenta pilnvaras. Rakstā šie 5. Saeimas lēmumi detalizētāk analizēti, izmantojot Saeimas stenogrammas, analizējamā perioda tiesībpolitiskās diskusijas, kā arī memuāru literatūru.

5. Saeimas konsekventā pozīcija sekmēja to, ka izveidojās parlamentārismam atbilstošas savstarpējās attiecības starp Saeimu, Ministru kabinetu un Valsts prezidentu. ${ }^{14}$ To faktiski nodrošināja savienība "Latvijas Celšs” kā neapstrīdami vadošais politiskais spēks 5. Saeimā (ieguva visvairāk Saeimas deputātu mandātu vēlēšanās, veidoja abus Ministru kabinetus 5. Saeimā un noteica valsts politikas būtiskākos jautājumus). Vadošie "Latvijas Cel̦a" politiķi (Valdis Birkavs, Māris Gailis, arī Egils Levits) savās runās un rakstos neslēpa atbalstu parlamentārās demokrātijas modelim un skeptiski vērtēja iespējas ieviest prezidentālās sistēmas elementus. ${ }^{15} \mathrm{Ka}$ minējis M. Gailis, "mūsu Satversmes noteiktā konsekventā parlamentārās demokrātijas sistēma vislabāk atbilst Latvijas politiskajai situācijai un latviešu tautas antiautoritārajai politiskajai mentalitātei un demokrātijas izpratnei". ${ }^{16}$

\section{Satversmes grozijumi}

Latviešu zemnieku savienība IV Saeimas pilnvaru termiṇā bija piedāvājusi veikt apjomīgu Satversmes revīziju, kurā parlamentārisms faktiski tiktu aizstāts ar prezidentālu sistēmu. ${ }^{17}$ IV Saeimas Publisko tiesību komisija Latviešu zemnieku savienības priekšlikumus būtiski pārstrādāja, gan paredzot tiešās vēlēšanās ievēlētu Valsts prezidentu ar paplašinātām pilnvarām, bet tajā pašā laikā saglabājot parlamentārismu kā valsts iekārtas formu. ${ }^{18}$ Saeimas Publisko tiesību komisijas sagatavoto projektu IV Saeimas vairākums atbalstīja divos lasījumos,

${ }^{13}$ Sk.: Pleps J. Satversmes iztulkošana tiesiskās transformācijas procesā. Grām.: Centrālās un Austrumeiropas juridiskās tradīcijas un juridiskās identitātes jautājumi. Latvijas Universitātes 76. starptautiskās zinātniskās konferences rakstu krājums. Rīga: LU Akadēmiskais apgāds, 2018, 158.-166. lpp.

14 Dimants A. Latvijas Cel̦am - nacionāli progresīvais spārns? Intervija ar Saeimas locekli Egilu Levitu. Diena, 1994, Nr. 219, 2. lpp. Plašāk sk.: Levits E. Satversme 1995. gada 18. novembrī. Diena, 1995, Nr. 270, 2. lpp.

15 Piemēra pēc sk.: Gailis M. Latvijai vajadzīga tautvaldība. Diena, 1995, Nr. 58, 2. lpp.; Levits E. 1995, 2. lpp.

${ }^{16}$ Gailis M. Varas tehnologija. Rìga: Jumava, 1997, 280. lpp.

17 Latvijas Republikas IV Saeimas VII sesijas 5. sēdes 1933. gada 3. novembrī stenogramma. Grām.: Latvijas Republikas IV Saeimas stenogrammas. Ārkārtējā un VII sesija. Rīga: Latvijas Republikas Saeimas izdevums, 1933, 292.-293. sl. Plašāk sk.: Ducmanis K. Latvijas un Igaunijas satversmes reformas jautājumi. Latvijas - Igaunijas biedrības mēnešraksts, 1933, Nr. 4-6, 7.-20. lpp.; Kusinš G. Latvijas Republikas 1922. gada Satversmes atjaunošana. Grām.: Nepārtrauktības doktrīna Latvijas vēstures kontekstā. Autoru kolektīvs prof. T. Jundža zinātniskā vadībā. Rīga: LZA Baltijas stratēgisko pētījumu centrs, 2017, 291.-297. lpp.

18 Plašāk sk.: Akmentiņš R. Latvijas Satversmes reforma (sakarā ar mēginājumiem izvest Satversmes pārgrozījumus Saeimā). Jurists, 1934, Nr. 4 (56), 105.-114. sl., Nr. 5 (57), 129.-148. sl. Sk. arī: Eglājs R. Kādi bija gandrīz, gandrīz pieņemtie 1934. gada Satversmes grozījumi, 15.05.2014. Pieejams: https://ritvars. wordpress.com/2014/05/15/kadi-bija-gandriz-gandriz-pienemtie-1934-gada-satversmes-grozijumi/ [aplūkots 28.03.2019.]. 
taču Satversmes revīzija netika pabeigta, jo to pārtrauca K. Ulmaņa īstenotais 1934. gada 15. maija apvērsums un autoritārā režīma nodibināšana.

Nepabeigtā Satversmes revīzija atspoguḷoja IV Saeimas vairākuma pārliecību, ka Satversmē noteiktais parlamentārisms ir saglabājams kā valsts iekārtas forma, taču nepieciešams labot atsevišķus tās trūkumus. Šì pārliecība atspoguḷojās arī nacionālās pretošanās kustības - Latvijas Centrālās padomes - 1944. gada februārī sagatavotajā politiskajā platformā. ${ }^{19}$ Tāpat trimdā turpinājās diskusija par nepieciešamību veikt Satversmes pilnveidojumus, lai novērstu parlamentārisma trūkumus. ${ }^{20}$

Pirmajā 5. Saeimas sēdē frakcijas "Saskaṇa Latvijai” priekšsēdētājs Edvīns Kide, lemjot par Satversmes darbības atjaunošanu pilnā apjomā, frakcijas vārdā rosināja turpināt IV Saeimas sākto Satversmes revīziju. Viņš aicināja "izdarīt tās nepieciešamās izmaiṇas Satversmēe kuras nepaguva izdarīt IV Saeima. Proti, noteikt, ka Latvijas Valsts prezidentu vispārējās vienlīdzīgās un tiešās vēlēšanās ievēlē visi pilntiesīgie Latvijas pilsoṇi. Deputātu frakcija "Saskaṇa Latvijai" ir sagatavojusi likuma projektu, kura galvenie principi ir šādi: 1) Valsts prezidentu uz 3 gadiem ievēlē nevis Saeima, bet Latvijas pilsoṇi; 2) Valsts prezidentu pirms termiṇa var atcelt no amata vienīgi tauta ar nobalsošanu; 3) jāpaplašina Valsts prezidenta pilnvaras likumu parakstī̌sanā un visai tautai svarīgu lēmumu pieñemšanā”. ${ }^{21}$

E. Kide rosināja atlikt Valsts prezidenta ievēlēšanu līdz Satversmes grozijjumiem: "Mēs ierosinām 5. Saeimai pieñemt lēmumu, ka līdz visas tautas vēlēta prezidenta ievēlēšanai Valsts prezidenta vietu izpilda Saeimas priekšsēdētājs." 22 Tā kā Saeimas vairākums izlēma sākt Valsts prezidenta vēlēšanas, frakcija "Saskaṇa Latvijai" Valsts prezidenta vēlēšanās nepiedalījās. ${ }^{23}$

Lai arī E. Kide aicināja turpināt IV Saeimas aizsākto darbu, frakcijas "Saskaṇa Latvijai” deputāti iesniedza jaunu Satversmes grozijumu projektu. Tomēr faktiski, kā uzsvēra deputāts Jānis Lucāns, "priekšlikums, kuru iesniedza mūsu frakcija pirms prezidenta vēlēšanām, būtībā bija jau 1934. gadā Saeimas pieṇemtais likumprojekts, tas bija otrajā lasījumā pieņemtā likumprojekta atkārtojums ar nelieliem grozījumiem, kas izdarīti atbilstoši tai situācijai, kāda bija pirms vēlēšanām". ${ }^{24}$

5. Saeimas darbam piemērojamais 1929. gada 10. aprīḷa Saeimas kārtības rullis neparedzēja iespēju nākamajai Saeimai pārņemt iepriekšējās Saeimas pilnvaru laikā uzsākto likumprojektu izskatīšanu. ${ }^{25}$ Saskaṇā ar 1929. gada 10. aprīḷa Saeimas kārtības ruḷla 40. pantu likumprojektus Saeima varēja turpināt izskatīt

19 Latvijas Centrālās padomes politiskā platforma. Grām.: Bīskaps Jāzeps Rancāns. Dzīve un darbs. Dr. H. Tichovska redakcijā. [B. v.]: Astras apgāds, 1973, 185.-187. lpp. Sk. arī: [B. a.] Latvijas Centrālā padome. Latviju Ziņas, 1945, Nr. 31, 3. lpp., Nr. 32, 4. lpp.

${ }^{20}$ Plašāk sk.: Deksnis E. B., Beķere K. Latvijas trimdas loma valsts neatkarības idejas uzturēšanā (1945-1991). Grām.: Nepārtrauktības doktrīna Latvijas vēstures kontekstā. Autoru kolektīvs prof. T. Jundža zinātniskā vadībā. Rīga: LZA Baltijas stratēǵgisko pētījumu centrs, 2017, 233.-236. lpp.

${ }^{21}$ Latvijas Republikas 5. Saeimas pirmās sēdes 1993. gada 6. jūlijā stenogramma. Pieejams: http://www. saeima.lv/steno/st_93/060793.html [aplūkots 28.03.2019.].

22 Ibid.

${ }^{23}$ Latvijas Republikas 5. Saeimas vakara sēdes 1993. gada 6. jūlijā stenogramma. Pieejams: http://www. saeima.lv/steno/st_93/060793.html [aplūkots 28.03.2019.].

${ }^{24}$ Latvijas Republikas 5. Saeimas plenārsēdes 1993. gada 16. septembrī stenogramma. Pieejams: http:// www.saeima.lv/steno/st_93/st1609.html [aplūkots 28.03.2019.].

${ }^{25}$ Ducmanis M. Parlaments savos rāmjos. Latvijas Saeimas Kārtības rullim - 75. Intervija ar 6. Saeimas sekretāru Induli Bērziṇu. Latvijas Vēstnesis, 1998, Nr. 82/83, 3. lpp. Lai gan sal.: Dišlers K. Ievads Latvijas valststiesību zinātnē. Rīga: A. Gulbis, 1930, 165. lpp. 
vairākās sesijās, bet to izskatīšanu nākamā Saeima nevarēja turpināt. ${ }^{26}$ Šādu iespēju Saeima paredzēja tikai ar 1998. gada 7. oktobra grozijumiem 1994. gada 28. jūlija Saeimas kārtības rullī, tajā ietverot 39. panta otro daḷu. ${ }^{27}$ Ja 5. Saeimas sanākšanas dienā būtu piemērojams pašlaik spēkā esošajai Saeimas kārtības ruḷı 39. panta otrajai daḷai līdzīgs regulējums, 5. Saeimai būtu iespēja turpināt izskatīt IV Saeimas līdz galam neizskatīto Satversmes grozījumu projektu. Tomēr arī simboliska atsauce uz nepieciešamību pabeigt IV Saeimas aizsāktos Satversmes grozījumus papildus apstiprina nostāju, ka 5. Saeima turpināja beidzamās Satversmes ietvaros leǵitīmi ievēlētās IV Saeimas darbu, proti, konstitucionāli starp tām nav bijušas Satversmei atbilstoši ievēlētas citas Saeimas. ${ }^{28}$ Lìdzīgi 5. Saeima pirmajā sēdē lēma par iespēju piemērot savam darbam 1929. gada 10. aprīḷa Saeimas kārtības rulli. ${ }^{29}$

5. Saeima frakcijas "Saskaņa Latvijai” iesniegtos Satversmes grozijumus noraidīja 1993. gada 16. septembra sēdē. ${ }^{30}$ Saeimas Juridiskās komisijas priekšsēdētājs Aivars Endziņš uzsvēra nepieciešamību nesasteigt Satversmes grozīšanu, jo "tikko Saeima ir izveidojusi valdību. Saeima ir ievēlējusi prezidentu un atjaunojusi Satversmes darbību pilnā apjomā. Satversme pilnā apjomā darbojas aptuveni trīs mēnešus. Acīmredzot pēc ilga pārtraukuma ir nepieciešams laiks, lai varētu apkopot Satversmes darbības pieredzi" ${ }^{31}$

Saeimas debatēs deputāts Pēteris Elferts akcentēja konstitucionālās stabilitātes nodrošināšanu: "Latvijas Republika tika veidota kā parlamentāra republika, kas bāzēta uz tās Satversmi - to pašu Satversmi, ko mēs atjaunojām, apliecinot to ar mūsu parakstiem šajā pašā zālē pirms neilga laika. Mums ir jārespektē tā Satversme, ko mēs katrs esam parakstījuši. [..] pēckara prezidentālās republikas Eiropā nav varējušas risināt valsts problēmas, bet tieši parlamentārās republikas ir nodrošinājušas valsts stabilitāti un augšupeju. [..] Domāju, ka pie tautas vēlēta prezidenta projekta caurskatīšanas varētu atgriezties pēc 10. Saeimas, bet tagad varētu nodrošināt mūsu valsts stabilitāti parlamentārā ceḷā atbilstoši valsts Satversmei." ${ }^{32}$

5. Saeimas vairākums bija pārliecināts, ka nav nepieciešamas straujas izmaiṇas Satversmē noteiktajā valsts iekārtā ar neprognozējamām konsekvencēm. ${ }^{33}$ Tajā laikā, piemēram, NVS valstīs faktiski bija jau izveidojušies režīmi, kurus varēja komentēt šādi: "Visās NVS valstīs ir prezidiāla sistēma - lai gan es neuzdrošinātos visas saukt par [..] demokrātijām." ${ }^{4}$ Satversmes grozijumu noraidī̌sana pasargāja valsts iekārtu no iespējamiem eksperimentiem ar tiešās vēlēšanās ievēlētu Valsts prezidentu un viṇa potenciālo konkurenci ar Saeimu, kas bija tajā laikā raksturīga

\footnotetext{
${ }^{26}$ Saeimas kārtības rullis: LV likums. Valdības Vēstnesis, 10.04.1929., Nr. 79.

27 Saeimas kārtības rullis: LV likums. [14.06.2016. red.].

${ }^{28}$ Kusiņš G., Pleps J. Valsts iekārtas un tiesību sistēmas atjaunošana. Grām.: Kučs A., Kusiņš G., Lazdiņš J., Pleps J. Latvijas valsts tiesību avoti. Valsts dibināšana - neatkarïbas atjaunošana. Dokumenti un komentāri. Rīga: Tiesu namu aǵentūra, 2015, 235. lpp.; Kusin̦š G. 2016, 62. lpp.

${ }^{29}$ Latvijas Republikas 5. Saeimas pirmās sēdes 1993. gada 6. jūlijā stenogramma. Pieejams: http:// www.saeima.lv/steno/st_93/060793.html [aplūkots 28.03.2019.]. Plašāk sk.: Kusiṇš G., Pleps J. 2015, 262.-264. lpp.

${ }^{30}$ Latvijas Republikas 5. Saeimas plenārsēdes 1993. gada 16. septembrī stenogramma. Pieejams: http:// www.saeima.lv/steno/st_93/st1609.html [aplūkots 28.03.2019.].

31 Ibid.

32 Ibid.

${ }^{33}$ Sk. arī: Cielava V. 1922. gada Satversme - veca dziesma jaunās skaṇās? Literatūra un Māksla, 1992, Nr. 16, 4. lpp.

${ }^{34}$ Dimants A. 1994, 2. lpp.
} 
regiona valstīm, kuras ieviesa tiešās vēlēšanās vēlētu prezidentu ar plašākām pilnvarām. ${ }^{35}$ Kā tolaik minēja E. Levits, "mēs esam faktiski vienīgā parlamentārā demokrātija starp bijušajām piecpadsmit PSRS republikām”. ${ }^{36}$ 5. Saeimas vairākums saglabāja tiesībpolitisko pozīciju par to, ka Satversmē noteiktais parlamentārisms ir īstenojams tiesiskajā realitātē un Satversmes stabilitāte ir svarīga vērtība, kura ir nodrošināma.

\section{Valsts prezidenta institūcijas atjaunošana}

5. Saeimas vēlēšanās visvairāk Saeimas deputāta mandātu ieguva "Latvijas Cel̦š", taču tam bija nepieciešams meklēt sadarbības partnerus, lai varētu izveidot Ministru kabinetu un īstenot savu politisko programmu. Lai gan "Latvijas Cel̦šs” pretendēja arī uz Valsts prezidenta amatu (kandidāts Gunārs Meierovics), šis amats viṇiem nebija izšķiroši svarīgs. "Latvijas Cel̦a" izvēlētajā stratēgijā Valsts prezidents nebija paredzēts kā institūcija, ar kuras palīdzību varētu būtiski ietekmēt politiskos procesus vai īstenot nepieciešamās reformas. "Latvijas Cel̦š" 5. Saeimas vēlēšanās solīja, ka Latvijā nostiprināsies parlamentārā demokrātija, ${ }^{37}$ un viṇu stratēgija paredzēja reformu īstenošanu, izmantojot Ministru kabineta un Saeimas pilnvaras. ${ }^{38}$ "Latvijas Ceḷam" daudz svarīgāk bija iegūt dominējošo lomu Ministru kabinetā un Saeimā. ${ }^{39}$ Atbilstoši parlamentārisma logíikai svarīgs bija vienīgi potenciālā Valsts prezidenta atbalsts Ministru kabineta un to atbalstošā Saeimas vairākuma īstenotajai politikai. ${ }^{40}$

Valsts prezidenta amats varēja būt tikai "būtisks politiskās tirgošanās priekšmets"41 valdības veidošanas sarunās. Ministru kabineta veidošanas laikā "Latvijas Cel̦am” bija svarīgi izvirzìt savus kandidātus gan finanšu, gan ekonomikas ministra amatam. Tā kā Latvijas Zemnieku savienība pretendēja uz finanšu ministra amatu, apmaiṇā pret atteikšanos no šā amata "Latvijas Ceḷš" garantēja Latvijas Zemnieku savienības izvirzītajam kandidātam Guntim Ulmanim atbalstu Valsts prezidenta vēlēšanās. ${ }^{42}$

1993. gada 7. jūlijā 5. Saeima ar 53 balsīm "par" G. Ulmani ievēlēja Valsts prezidenta amatāa, ${ }^{43}$ un 1993. gada 8. jūlijā G. Ulmanis deva Valsts prezidenta svinīgo solījumu. ${ }^{44}$ Šāda izvēle bija stratēgésiski pareiza parlamentārisma nostiprināšanai, jo G. Ulmanis Valsts prezidenta institūciju atjaunoja atbilstoši Satversmei un

\footnotetext{
${ }^{35}$ Par šiem riskiem plašāk sk.: Ikstens J. Vai Satversmes reforma var veicināt atbildīgu politiku. Jurista Vārds, 2002, Nr. 4, 12.-15. lpp., Nr. 5, 12. lpp.

36 Dimants A. 1994, 2. lpp.

37 Solījumi 5. Saeimas vēlētājiem (oficiālie dokumenti, kas iesniegti Centrālajai vēlēšanu komisijai). Diena, pielikums "Latvijas Republikas Augstākās padomes un Ministru padomes oficiālie dokumenti, skaidrojumi, informācija”, 1993, Nr. 20, 4. lpp.

38 Latvijas Cel̦a programma. Latvijas ceḷš - Latvijas tautai. Laiks, 1993, Nr. 37, 6. lpp. Sk. arī: Mednis I. Partiju laiki Latvijā (1988-2002). Rīga: Drukātava, 2007, 146. lpp.

39 Sk. arī: Peniķis J. Jauna Saeima - jauns laikmets Latvijai? Literatūra un Māksla, 1993, Nr. 35, 1., 3. lpp.

40 Ūdris J. Gunta Ulmaņa vertikāle. Rīga: Jumava, 2009, 66. lpp.

41 Gailis M. 1997, 91. lpp.

42 Ibid., 90.-91. lpp.

${ }^{43}$ Latvijas Republikas 5. Saeimas pirmās sēdes 1993. gada 7. jūlijā stenogramma. Pieejams: http://www. saeima.lv/steno/st_93/060793.html [aplūkots 28.03.2019.].

${ }^{44}$ Latvijas Republikas 5. Saeimas sēdes 1993. gada 8. jūlijā stenogramma. Pieejams: http://www.saeima. lv/steno/st_93/080793.html [aplūkots 28.03.2019.].
} 
parlamentārisma idejām pirmā Valsts prezidenta Jāṇa Čakstes tradīciju garā. ${ }^{45}$ Ministru prezidents M. Gailis uzsvēra, ka "Valsts prezidents nav ḷāvies sevi iesaistīt šajā pret Satversmi vērstajā diskusijā [..] Valsts prezidents, tāpat kā "Latvijas Cel̦š̀, bez ierunām atbalsta mūsu Satversmes noteikto parlamentārās demokrātijas iekārtu" ${ }^{46}$

Latvijas valsts iekārtai nekad nav bijuši raksturīgi politiski konflikti starp Saeimas vairākumu un Valsts prezidentu, kuri varētu apdraudēt valsts iekārtas stabilitāti un radìt konkurenci cīṇā par politisko ietekmi. 5. Saeimas vārdā šo faktoru kā būtisku sasniegumu minēja Saeimas priekšsēdētājs Anatolijs Gorbunovs, uzrunājot Valsts prezidentu G. Ulmani: "Ar savu attieksmi pret Saeimu jūs esat balstijis parlamentārismu. Katrā ziṇā, pateicoties arī jūsu izpratnei un atbildības sajūtai, Latvijā nav izveidojusies šḳirtne starp prezidenta institūtu un parlamentu." 47 Tas l̦āva stabilizēt parlamentārismu pirmajos tā pastāvēšanas gados pēc Satversmes darbības atjaunošanas, un Valsts prezidents kḷuva par Satversmē noteiktās valsts iekārtas sargātāju, nevis kritiḳi vai Satversmes reformu virzītāju.

G. Ulmanis gan savā pilnvaru termiṇā vairoja ietekmi un paplašināja savas pilnvaras, taču tas notika saskaņā ar Satversmi un neradija sadursmes ar Saeimas vairākumu jeb kompetenču strīdus. ${ }^{48}$ Pats G. Ulmanis šādu Satversmes lasījumu raksturoja kā politisku dialogu starp Valsts prezidentu un Saeimu: "5. Saeimas laikā iezīmējās lietišḳa sadarbība starp Saeimu un Valsts prezidenta institūciju. Šì sadarbība noteikti ir uzskatāma par nozīmīgu sastāvdaḷu Latvijas demokrātijā. [..] arī turpmāk vadīšos no Prezidentam Satversmē paredzētās demokrātijas garanta lomas un vienmēr mēgināšu rast izpratni ar Saeimu kā demokrātijas sistēmas galveno balstu." 49

Valsts prezidenta G. Ulmaņa un 5. Saeimas sadarbība l̦āva nostiprināties parlamentārismam - Valsts prezidentam ir galvenokārt reprezentācijas, padomdevēja un kontroles uzdevumi, bet ne aktīva valsts varas orgāna loma, un viņš politiski nekonkurē ar Saeimu vai tās izveidoto Ministru kabinetu. ${ }^{50}$ Tādā veidā tika atjaunota Satversmei raksturīgā izpratne, ka "Valsts prezidents ir patstāvīga, pati par sevi pastāvoša vara un nav iekḷaujama citās varās. Valsts prezidents ir valsts galva, kura galvenais uzdevums, stāvot ārpus šauri politisku lēmumu pieņemšanas, ir konsolidēt visas pārējās valsts varas". ${ }^{51}$

45 Ūdris J. 2009, 162. 1pp.

${ }^{46}$ Gailis M. 1997, 288. lpp.

${ }^{47}$ Latvijas Republikas 5. Saeimas noslēguma sēdes 1995. gada 6. novembrī stenogramma. Pieejams: http://www.saeima.lv/steno/st_955/st0611.html [aplūkots 28.03.2019.].

${ }^{48}$ Cielava V. Diskusija par Satversmes grozijumu nepieciešamību. Likums un Tiesības, 2. sēj., 2000, Nr. 6 (10), 167. lpp.

${ }^{49}$ Latvijas Republikas 5. Saeimas noslēguma sēdes 1995. gada 6. novembrī stenogramma. Pieejams: http://www.saeima.lv/steno/st_955/st0611.html [aplūkots 28.03.2019.].

${ }^{50}$ Levits E. 1995, 2. lpp. Lai gan sal.: Strupišs A. Parlamentārisma un prezidentālisma dilemmas. Grām.: Satversmes reforma Latvijā: par un pret. Rīga: Sociāli ekonomisko pētījumu institūts "Latvija", 1995 , 49.-51. lpp.

${ }^{51}$ Jelāgins J. Konstitucionālās reformas cel̦i. Grām.: Satversmes reforma Latvijā: par un pret. Rīga: Sociāli ekonomisko pētījumu institūts "Latvija", 1995, 30. lpp. 


\section{Valsts prezidenta pilnvaru apjoms}

Pēc Satversmes darbības atjaunošanas pilnā apjomā likumus, kas detalizētāk noteica valsts varas orgānu pilnvaras, bija nepieciešams saskaņot ar Satversmē noteikto valsts iekārtu. 5. Saeima šo uzdevumu veica, gan atjaunojot starpkaru perioda likumus, gan arī izstrādājot jaunus likumus vai grozot vēl Augstākās padomes laikā pieṇemtos likumus. ${ }^{52}$ Vairāku likumu apspriešanas gaitā kḷuva aktuāls Valsts prezidenta pilnvaru regulējums, proti, šim periodam bija raksturīgi priekšlikumi, lai ar likumiem piešķirtu arvien jaunas pilnvaras Valsts prezidentam.

Piemēram, Augstākās padomes 1992. gada 15. decembra likums "Par tiesu varu" jau paredzēja, ka Valsts prezidents pieņem tiesnešu zvērestus, kā arī Valsts prezidentam tika piešķirtas tiesības ierosināt Saeimai iecelt amatā Augstākās tiesas priekšsēèēāju, atbrīvot vinu no amata vai pagarināt vina atrašanos amatā. ${ }^{53}$ Līdzīgi tika piedāvāts noteikt, ka Valsts prezidents izvirza iecelšanai amatā generālprokuroru un var rosināt atbrīvot viņu no amata. ${ }^{54}$ Tāpat tika sagatavoti likuma grozijumi, kas paredzēja Valsts prezidenta tiesības izvirzīt apstiprināšanai Saeimā Latvijas Bankas prezidenta un valsts kontroliera amata kandidātus, kā arī rosināt viņu atbrīvošanu no amata. ${ }^{55}$ 1993. gada 11 . novembrī 5. Saeima pieņēma likumu, ar kuru tika izveidota Nacionālās drošības padome un noteikts, ka tās sēdes vada Valsts prezidents. ${ }^{56}$

Papildu pilnvaru pieškiršana Valsts prezidentam tika motivēta ar nepieciešamību attiecīgajā jomā nodrošināt lielāku neatkarību no Ministru kabineta un parlamentārā vairākuma. Piemēram, attiecībā uz priekšlikumu par Latvijas Bankas prezidenta amata kandidāta izvirzīšanu deputāts Jānis Lagzdiņ̧̌ uzsvēra: "Ja mēs Valsts prezidentam dodam tiesības izvirzìt tik svarīgas institūcijas, kāda ir Latvijas Banka, prezidentu un - pèc analog̣ijas - arī tiesības izvirzìt jautājumu par viṇa atcelšanu no amata, tad, manuprāt, šajā gadījumā Latvijas Bankas stabilitāte tiktu vairāk garantēta nekā tad, ja šādas tiesības tiktu dotas, piemēram, pieciem deputātiem (kā to daudzos gadījumos paredz Kārtības rullis) vai arī, teiksim, Saeimas komisijām vai Ministru kabinetam. Mūsu komisijas mērḳis bija radìt šo stabilitāti Latvijas Bankas darbībā." ${ }^{\prime 7}$

Tomēr šajos priekšlikumos kopumā iezīmējās parlamentārismam bīstama tendence - ar likumu starpniecību piešķirt arvien vairāk pilnvaru Valsts prezidentam, tādējādi samazinot pašas Saeimas un Ministru kabineta pilnvaru apjomu. Saeimas Juridiskais birojs pamatoti atzina, ka šādu priekšlikumu atbalstī̌šana "var radìt nopietnas konstitucionālas problēmas". ${ }^{58}$ Tādā veidā faktiski varēja radìt

${ }^{52}$ Kusiņš G., Pleps J. 2015, 238. lpp.

53 Par tiesu varu: LV likums. Latvijas Republikas Augstākās Padomes un Valdības Ziņotājs, 1993, Nr. 1/2.

${ }^{54}$ Latvijas Republikas 5. Saeimas plenārsēdes 1994. gada 19. maijā stenogramma. Pieejams: http://www. saeima.lv/steno/st_94/st1905.html [aplūkots 28.03.2019.].

${ }^{55}$ Latvijas Republikas 5. Saeimas plenārsēdes 1993. gada 23. septembrī stenogramma. Pieejams: http:// www.saeima.lv/steno/st_93/st2309.html [aplūkots 28.03.2019.].

56 Nacionālās drošības padomes likums: LV likums. Latvijas Vēstnesis, 1993, Nr. 108.

57 Latvijas Republikas 5. Saeimas plenārsēdes 1993. gada 23. septembrī stenogramma. Pieejams: http:// www.saeima.lv/steno/st_93/st2309.html [aplūkots 28.03.2019.].

58 Par likumprojektā paredzētajām Valsts prezidenta tiesībām izvirzìt genenerālprokurora amata kandidātus. Saeimas Juridiskā biroja 1994. gada 16. marta vēstule tieslietu ministram E. Levitam. Grām.: Saeimas Juridiskā biroja dokumenti. 1993-2013. Juridisku secinājumu kopojums atzinumos un vēstulēs. Rīga: Latvijas Vēstnesis, 2013, 38. lpp. 
priekšnoteikumus Valsts prezidenta un Saeimas vairākuma politiskiem konfliktiem un dot iespēju Valsts prezidenta institūciju attīstīt kā konkurējošu varas centru. Šādu ideju popularitāti ietekmēja salīdzinoši mazā izpratne par parlamentāras republikas prezidenta lomu un daudz labākas zināšanas par valsts iekārtām, kurās prezidentam bija dominējošā loma (piemēram, ASV, Francija, arī Krievija). ${ }^{59}$

5. Saeimai šo priekšlikumu apspriešanas gaitā bija politiski jāizšksiras par to, kādā veidā attīstāma Latvijas valsts iekārta. 5. Saeimas vairākums tiesībpolitiski izšḳirās nepiešksirt papildu funkcijas Valsts prezidentam ar likumiem. ${ }^{60}$ Diemžēl šì konceptuālā izšķiršanās tika nevis izdarìta atklātā diskusijā, bet paslēpta aiz škietami juridiskas Satversmes iztulkošanas. Par šiem jautājumiem Saeimas Juridiskais birojs sniedza vairākus atzinumus. ${ }^{61}$ Tajos Satversmes iztulkošanas ceḷā tika nonākts līdz secinājumam, ka "Valsts prezidenta pilnvaru uzskaitījums Satversmē tiek uzskatīts par izsmel̦ošu”. ${ }^{62}$ Par šādu Satversmes iztulkojumu jau tajā laikā pastāvēja šaubas. Kā Saeimas debatēs minēja deputāts Andris Līgotnis, "mēs [komisijā] ilgi diskutējām, uzskatot to, ka šìs funkcijas Satversmē nav izsmel̦ošas pilnīgi un nekur tāds aizliegums nav". ${ }^{63}$ Tomēr kopumā dominēja vēlme "izvairīties no šīs juridiski divdomīgās situācijas". ${ }^{64}$

Pārskatot Saeimas Juridiskā biroja sniegto secinājumu pamatojumu, ir pamats saprātīgām šaubām par pienācīgi veiktu Satversmes iztulkošanu. Saeimas Juridiskais birojs minēja, ka "nevienā [starpkaru perioda] likumā Valsts prezidentam nav dotas nekādas papildu pilnvaras, kas neizrietētu no viṇa pilnvaru uzskaitījuma Satversmē" ${ }^{65}$ Tomēr starpkaru periodā bija pieņemti atsevišķi likumi, kas noteica Valsts prezidenta pilnvaras papildus Satversmes ietvaram. Piemēram, Latvijas Satversmes sapulce 1922. gada 9. jūnijā pieņēma Likumu par Saeimas vēlēšanām, kura 4. pantā bija paredzēts, ka viens no Centrālās vēlēšanu komisijas locekḷiem ir Valsts prezidenta pilnvarota persona. ${ }^{66}$ Tāpat Saeimas Juridiskais birojs secinājumu, ka "Valsts prezidenta pilnvaru uzskaitījums Satversmē tiek uzskatīts par

59 Plašāk sk.: Cielava V. Valsts prezidents - tas skan lepni. Diena, 1993, Nr. 124, 2. lpp.

${ }^{60}$ Latvijas Republikas 5. Saeimas plenārsēdes 1994. gada 19. maijā stenogramma. Pieejams: http://www. saeima.lv/steno/st_94/st1905.html [aplūkots 28.03.2019.].

${ }^{61}$ Par sagatavotajiem grozijumiem likumā "Par Latvijas Banku”. Saeimas Juridiskā biroja 1993. gada 6. oktobra atzinums. Grām.: Saeimas Juridiskā biroja dokumenti. 1993-2013. Juridisku secinājumu kopojums atzinumos un vēstulēs. Rīga: Latvijas Vēstnesis, 2013, 32.-33. lpp.; Par likumprojektā paredzētajām Valsts prezidenta tiesībām izvirzīt ġenerālprokurora amata kandidātus. Saeimas Juridiskā biroja 1994. gada 16. marta vēstule tieslietu ministram E. Levitam. Grām.: Saeimas Juridiskā biroja dokumenti. 1993-2013. Juridisku secinājumu kopojums atzinumos un vēstulēs. Rìga: Latvijas Vēstnesis, 2013, 37.-38. lpp.

${ }^{62}$ Par sagatavotajiem grozījumiem likumā "Par Latvijas Banku”. Saeimas Juridiskā biroja 1993. gada 6. oktobra atzinums. Grām.: Saeimas Juridiskā biroja dokumenti. 1993-2013. Juridisku secinājumu kopojums atzinumos un vēstulēs. Rīga: Latvijas Vēstnesis, 2013, 32. lpp.

${ }^{63}$ Latvijas Republikas 5. Saeimas plenārsēdes 1994. gada 19. maijā stenogramma. Pieejams: http://www. saeima.lv/steno/st_94/st1905.html [aplūkots 28.03.2019.].

64 Ibid.

${ }^{65}$ Par sagatavotajiem grozījumiem likumā "Par Latvijas Banku”. Saeimas Juridiskā biroja 1993. gada 6. oktobra atzinums. Grām.: Saeimas Juridiskā biroja dokumenti. 1993-2013. Juridisku secinājumu kopojums atzinumos un vēstulēs. Rīga: Latvijas Vēstnesis, 2013, 32. lpp.

${ }^{66}$ Likums par Saeimas vēlēšanām: LV likums. Valdības Vēstnesis, 1922, Nr. 141. 
izsmel̦ošu”, pamatoja ar atsauci uz Kārḷa Dišlera darbu. ${ }^{67}$ Tomēr attiecīgajā avotā K. Dišlers nekādā veidā neizsakās par to, ka Valsts prezidenta pilnvaras būtu izsmel̦ošas, bet gan tikai sistematizē vienkopus iepriekš aplūkotās Valsts prezidenta pilnvaras. ${ }^{68}$ Lìdzīgā tehnikā K. Dišlers šajā darbā to darījis arī ar Saeimas pilnvaru uzskaitījumu. ${ }^{69}$ Tomēr no šà neviens neuzskatītu par iespējamu taisīt secinājumu, ka Saeimas pilnvaras šādā uzskaitījumā ir minētas izsmel̦oši. Līdzīgs secinājums korekti būtu izdarāms arī par K. Dišlera sniegto Valsts prezidenta pilnvaru uzskaitījumu. Citā darbā K. Dišlers īpaši iedalījis Valsts prezidenta pilnvaras tādās, kuras ir Satversmē minētas, un tādās, kuras ir Satversmē neminētas. ${ }^{70}$ Var piel̦aut, ka Saeimas Juridiskā biroja pārliecỉbu par Valsts prezidenta pilnvaru izsmelıšo raksturu stiprināja arī konkrētas normas trūkums Satversmes tekstā, kurā būtu uzsvērts, ka Valsts prezidentam var būt arī citas ar likumiem noteiktas pilnvaras.

5. Saeimas vairākums akceptēja šādu Satversmes iztulkojumu un konsekventi to īstenoja praksē. ${ }^{71}$ 5. Saeimas noslēguma sēdē Saeimas priekšsēdētājs A. Gorbunovs īpaši atgādināja, ka Valsts prezidenta loma Satversmē noteikta izsmel̦oši. ${ }^{72}$ Šāda Satversmes izpratne sekmēja parlamentārisma nostiprināšanos un novērsa potenciālu konfliktu riskus starp Saeimas vairākumu un Valsts prezidentu, nepiel̦aujot Valsts prezidenta kḷū̌̌anu par alternatīvu vai konkurējošu varas centru Saeimas vairākumam. Tas bija būtisks sasniegums Satversmē noteiktās valsts iekārtas stabilitātes nodrošināšanā.

Šāds Satversmes iztulkojums bija tiesībpolitiski nepieciešams konkrētajos faktiskajos apstākḷos, ar kuriem saskārās 5. Saeima pēc Satversmes darbības atjaunošanas pilnā apjomā. Tomēr tā dogmatiska un mehāniska uzturēšana spēkā vairāk nekā divdesmit gadu pēc tā formulěšanas atsevišķos gadijumos ir liegusi likumdevējam iespēju izvēlēties jēdzīgus risinājumus. ${ }^{73}$ Tādẹḷ pozitīvi vērtējama arvien konsekventāka gatavība pārskatīt šo Satversmes iztulkojumu, kas mūsdienu kontekstā ir novecojis un drīzāk kavē valsts iekārtas funkcionēšanas uzlabošanu. ${ }^{74}$

${ }^{67}$ Par likumprojektā paredzētajām Valsts prezidenta tiesībām izvirzīt generālprokurora amata kandidātus. Saeimas Juridiskā biroja 1994. gada 16. marta vēstule tieslietu ministram E. Levitam. Grām.: Saeimas Juridiskā biroja dokumenti. 1993-2013. Juridisku secinājumu kopojums atzinumos un vēstulēs. Rīga: Latvijas Vēstnesis, 2013, 37. lpp. Atsauce uz: Dišlers K. Latvijas valsts varas orgāni un viņu funkcijas. Rīga: Tieslietu Ministrijas Vēstneša izdevums, 1925, 110.-111. lpp.

${ }^{68}$ Dišlers K. 1925, 110.-111. lpp.

${ }^{69}$ Ibid., 90.-91. lpp.

70 Dišlers K. Latvijas Valsts prezidenta kompetence. Tieslietu Ministrijas Vēstnesis, 1922, Nr. 3, 107.-127. lpp.

${ }^{71}$ Latvijas Republikas 5. Saeimas plenārsēdes 1994. gada 19. maijā stenogramma. Pieejams: http://www. saeima.lv/steno/st_94/st1905.html [aplūkots 28.03.2019.].

72 Latvijas Republikas 5. Saeimas noslēguma sēdes 1995. gada 6. novembrī stenogramma. Pieejams: http://www.saeima.lv/steno/st_955/st0611.html [aplūkots 28.03.2019.].

73 Plašāk sk.: Pleps J. Kur meklējamas Valsts prezidenta kompetences robežas. Jurista Vārds, 2005, Nr. 48, 8.-12. lpp.

74 Sk., piemēram: Patstāvīgo iestāžu darbības pilnveidošanas iespējas: Ekspertu grupas pārvaldības pilnveidei priekšlikumi. Grām.: Priekšlikumi Latvijas publiskās varas pilnveidošanai. Ekspertu grupas pārvaldības pilnveidei materiāli. Rīga: Latvijas Vēstnesis, 2015, 99.-100. lpp.; 12. Saeimas Juridiskās komisijas deputātu darba grupas Valsts prezidenta pilnvaru iespējamai paplašināšanai un ievēlēšanas kārtības izvērtēšanai atzinums, 18.-23. lpp. Pieejams: http://saeima.lv/lv/par-saeimu/saeimas-darbs/ deputatu-grupas/darba-grupa-valsts-prezidenta-pilnvaru-iespejamai-paplasinasanai-un-ievelesanaskartibas-izvertesana [aplūkots 17.04.2019.]. 


\section{Kopsavilkums}

1. Satversmes darbības atjaunošana pilnā apjomā un parlamentārisma saglabāšana bija pareizs tiesībpolitisks lēmums. 5. Saeimas pilnvaru termināa tika nostiprināts parlamentārisms, un 5. Saeimas vairākums novērsa potenciālos apdraudējumus Satversmē noteiktās valsts iekārtas atjaunošanai tiesiskajā realitātē.

2. Valsts prezidenta institūcijas darbïba tika atjaunota saskaņā ar Satversmi un parlamentārisma idejām. Valsts prezidenta G. Ulmaņa un 5. Saeimas vairākuma politiskais dialogs bija vērsts uz Satversmes un parlamentārisma nostiprināšanu. Valsts prezidenta institūcija nekḷıva par konkurējošu varas centru Saeimai, un Latvijas valsts iekārtai nav raksturīgi politiski konflikti starp Valsts prezidentu un Saeimas vairākumu.

3. Parlamentārisma nostiprināšanu sekmēja atbilstoša Satversmes normu iztulkošana, kas novērsa mēgeinājumus apiet Satversmes regulējumu un stiprināja Satversmes autoritāti. Šim periodam gan raksturīga būtisku lēmumu paslēpšana aiz tehniskiem juridiskiem atzinumiem, izvairoties no tiesībpolitiskas vērtību diskusijas. 